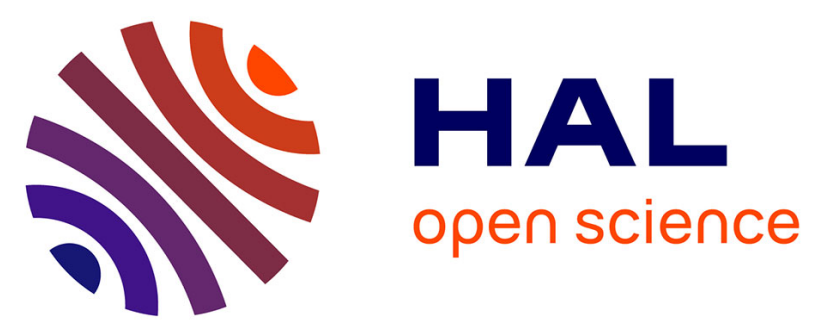

\title{
ANALYTICAL METHODS FOR SCREENING OF POTENTIAL VOLATILE MIGRANTS FROM ACRYLIC-BASE ADHESIVES USED IN FOOD CONTACT MATERIALS
}

Cristina Nerin, Elena Canellas, Margarita Aznar, Paul Silcock

\section{To cite this version:}

Cristina Nerin, Elena Canellas, Margarita Aznar, Paul Silcock. ANALYTICAL METHODS FOR SCREENING OF POTENTIAL VOLATILE MIGRANTS FROM ACRYLIC-BASE ADHESIVES USED IN FOOD CONTACT MATERIALS. Food Additives and Contaminants, 2009, 26 (12), pp.1592-1601. 10.1080/02652030903161572 . hal-00573888

\section{HAL Id: hal-00573888 https://hal.science/hal-00573888}

Submitted on 5 Mar 2011

HAL is a multi-disciplinary open access archive for the deposit and dissemination of scientific research documents, whether they are published or not. The documents may come from teaching and research institutions in France or abroad, or from public or private research centers.
L'archive ouverte pluridisciplinaire HAL, est destinée au dépôt et à la diffusion de documents scientifiques de niveau recherche, publiés ou non, émanant des établissements d'enseignement et de recherche français ou étrangers, des laboratoires publics ou privés. 


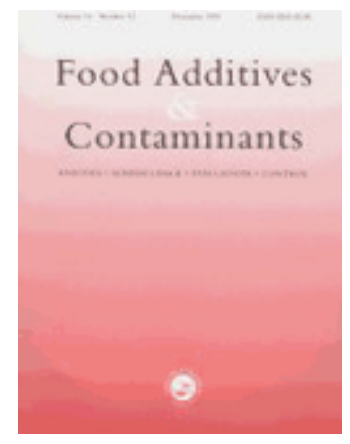

\section{ANALYTICAL METHODS FOR SCREENING OF POTENTIAL VOLATILE MIGRANTS FROM ACRYLIC-BASE ADHESIVES USED IN FOOD CONTACT MATERIALS}

\begin{tabular}{|c|c|}
\hline Journal: & Food Additives and Contaminants \\
\hline Manuscript ID: & TFAC-2008-410.R1 \\
\hline Manuscript Type: & Special Issue \\
\hline $\begin{array}{r}\text { Date Submitted by the } \\
\text { Author: }\end{array}$ & 25-Jun-2009 \\
\hline Complete List of Authors: & $\begin{array}{l}\text { Nerin, Cristina; University of Zaragoza, Analytical Chemistry } \\
\text { Canellas, Elena; university of Zaragoza, Analytical Chemistry } \\
\text { aznar, margarita; University of Zaragoza, Analytical Chemistry } \\
\text { SILCOCK, PAUL; Waters Corporation, Research Center Manchester }\end{array}$ \\
\hline Methods/Techniques: & $\begin{array}{l}\text { Chromatographic analysis, Chromatography - GC/MS, Clean-up - } \\
\text { SPME, Headspace }\end{array}$ \\
\hline Additives/Contaminants: & Additives general, Food contact materials, Migration, Packaging \\
\hline Food Types: & \\
\hline
\end{tabular}

\section{SCHOLARONE \\ Manuscripts}




\section{ANALYTICAL METHODS FOR SCREENING OF POTENTIAL VOLATILE}

2 MIGRANTS FROM ACRYLIC-BASE ADHESIVES USED IN FOOD CONTACT

3

4

5 C.Nerín*, E.Canellas ,M.Aznar and ${ }^{2}$ P.Silcock

6 Analytical Chemistry Department, GUIA Group, I3A, CPS

7 University of Zaragoza, Ma de Luna 3, 50018 Zaragoza, Spain.

8 cnerin@unizar.es

$9{ }^{2}$ Waters Corporation, Manchester, UK

\section{Abstract}

12 Two different analytical techniques, were studied for screening the volatile compounds

13 present in pure adhesives and those coming from the adhesives in different laminates.

14 Three different adhesive formulations were used for the study, all of them acrylic-based 15 and supplied by different producers. Laminates with polypropylene and paper, 16 polypropylene and polyethylene and aluminium and polyethylene as substrates were 17 prepared and studied. Adhesives themselves were acetonitrile extracted and volatiles identified by time-of-flight mass spectrometry based on accurate mass measurement of

Keywords: screening, adhesives, food packaging, GC-TOF-MS, SPME, laminates, analysis, migration, acrylic 


\section{Introduction}

35 Most food packages and food contact materials are multilayer materials manufactured 36 using different substrates and adhesives. Although most of the substrates have to fulfil 37 the legislation for being in contact with food (Directives 2002/72 EU, 2007/19/EC for 38 plastics and Resolution AP 2002 approved by the Council of Europe for paper and 39 boards), adhesives, are not yet regulated.

40

41 The adhesive industry uses a large variety of raw materials in food packaging, both natural and synthetic (Booth, 1990). Apart from the polymer, an adhesive formulation may contain the carrier, plasticizers, tackifiers, thickeners, fillers, surfactants, biocides and fungicides, emulsifiers, waxes and antioxidants (Ashley et al. 1995).

The study of adhesives is a difficult task for many reasons: a) There are many different formulations and standardization is not possible; b) There are a wide variety of substrates, such as plastics, paper and board, aluminium foil, cork or wood; c) The number of compounds involved in the adhesives formulation is very high and no information is provided about them by the companies; d) Migration behaviour is unknown and has never been tested. Adhesives are not as yet regulated mainly due to 52 these difficulties. Only in extremely limited cases such as the polyurethane based 53 adhesive layers, a clear legal restriction appears, specifically for aromatic amines, which migration restriction is 'non-detectable' at $0.010 \mathrm{mg} / \mathrm{kg}$ (Commission Directive 2002/72/EC and Directive 19/2007/EC).

All these facts highlight a strong need to develop a solution for this problem, and for this reason, the European Commission decided to finance the EU Project Migresives, in which frame the work reported here has been carried out [www.migresives.eu].

61 The analysis of adhesives is the first step to find out which substances could diffuse 62 throughout the different layers and migrate to the food in contact with them (Gruner and 63 Piringer et al. 1999). Nowadays it is well accepted that molecules of molecular mass 64 lower than 1000 daltons can migrate (Figge 1996, Jickells 1997), both in direct and indirect contact with the food, as the diffusion rates are high enough to cross the barrier 
66 of the materials. Diffusion rates are higher for volatile compounds, for this reason, the 67 volatiles are the priority migrants to be studied.

68

69 Several analytical procedures can be used for screening the potential volatile migrants 70 coming from the adhesives. The determination of potential migrants in a food contact material usually involves an extraction step followed by the analysis using a chromatographic method. However, sample handling is often time-consuming for fast screening procedures. The methods based on the direct analysis of the headspace by gas chromatography-mass spectrometry (GC-MS) permit the fast identification of migrants with a minimum sample handling but they usually does not provide enough sensitivity (Nerín et al, 2000). Advanced analytical techniques such as GC-TOF-MS (time of flight) provide an accurate mass measurement of ions in mass spectra (Mamyrin 2000) and for this reason has been widely used to identify target and non-target compounds (Marsman et al.2008, Marsman et al. 2007, Setkova et al. 2007, Bianchi et al.2007, Hao et al. 2005, Meruva et al.2004). This technique combined with ChromaLynx software, able to deconvolve complex mass spectra, allows a reliable identification of the compounds and it was used in this work in order to identify the compounds present in the pure adhesives.

An alternative for screening purposes is the analysis of the headspace by solid phase microextraction (HS-SPME) coupled to GC-MS. HS-SPME offers several advantages versus other methods (Pawliszyn 1997, Pawliszyn 1999, Wercinski 1999), mainly a considerably improvement of the sensitivity (Nerín et al, 2008), for this reason, it has been shown as a powerful tool to analyse different solid and liquid samples (Yang et al.2008, da Silva 2008, Pena 2008, Batlle et al, 2001; Nerín et al, 2002; Lopez et al. 2006, Domeno et al. 2005, Salafranca et al. 1999 and Batlle et al. 1999). In this work, HS-SPME-GC-MS was used in the screening of laminates, since they contained a low quantity of adhesive and a high sensitivity was necessary.

Materials and methods

\section{Materials and reagents}

97 Three acrylic adhesives were selected for this study (adhesive 1, 2 and 3) and they were 98 supplied by three adhesive companies. They were representative of commonly used adhesives in commercial food packaging but their origin and main characteristics are 
100 confidential and cannot be explained here. The laminates studied in this work were

101 either supplied by the companies or prepared in the laboratory: Laminate 1 was 102 prepared with adhesive 1 (grammage $45 \mathrm{~g} \mathrm{~m}^{-2}$ ) between aluminum foil and polyethylene 103 (PE) (40 $\mu \mathrm{m}$ thickness); laminate 2 was made using the adhesive 2 (grammage $18 \mathrm{~g} \mathrm{~m}^{-2}$ ) 104 between polypropylene (PP) ( $25 \mu \mathrm{m}$ thickness) and PE (40 $\mu \mathrm{m}$ thickness); and laminate 1053 was made using the adhesive 3 (grammage $12 \mathrm{~g} \mathrm{~m}^{-2}$ ) with polypropylene $(17.5 \mu \mathrm{m}$ 106 thickness) and paper ( $70 \mu \mathrm{m}$ thickness).

107

108 Three different SPME fibers were used in this work, $65 \mu \mathrm{m}$ PDMS/DVB, $85 \mu \mathrm{m}$ 109 Polyacrylate and $100 \mu \mathrm{m}$ PDMS. Fibers were supplied by Supelco (Bellefonte, PA, 110 USA). Acetonitrile was from J.T. Baker (Deventer, The Netherlands). 1-Hexanol-2111 ethyl, 2-ethylhexylacetate, 2-ethylhexylacrylate, ethanol, 2-2(butoxyethoxy), dimethyl 112 adipate, ethanol, 2-2(butoxyethoxy) acetate and 2,4,7,9-tetramethyl-5-decyne-4,7-diol 113 standards were supplied by Sigma-Aldrich (St. Lois, MO, USA).

\section{Sample preparation}

116 For the GC-TOF-MS analysis, $1 \mathrm{~g}$ of pure adhesive sample (non cured) was extracted 117 with $10 \mathrm{~g}$ of acetonitrile. Then, this solution was filtered using $0.22 \mu \mathrm{m}$ pore size filters 118 in order to remove the acrylic polymer that had precipitated when the acetonitrile was 119 added. After this step, samples were diluted 1/100 with acetonitrile and directly injected 120 into the GC.

122 For the HS- GC-MS and HS-SPME-GC-MS analysis, $1 \mathrm{~cm} \times 1 \mathrm{~cm}$ laminates prepared 123 from the pure materials and using about $20 \mathrm{~g} \cdot \mathrm{m}^{-2}$ of adhesive were cut and placed into $12420 \mathrm{~mL}$ headspace vials.

126 For the migration studies a cell consisting of two plates of aluminium, among which a 127 constant pressure could be applied was used. Two films of PE $(40 \mu \mathrm{m})$ were placed at 128 each side of the laminateand this stack was placed between the plates and stored at $40^{\circ} \mathrm{C}$ 129 for one hour. Then the cell was opened and each PE film was placed in $20 \mathrm{~mL}$ vials and 130 analysed by HS-SPME-GC-MS. Virgin PE films were also analysed with the same 131 technique. 
132 Calibration curves were prepared placing the same amount of PE in $20 \mathrm{~mL}$ vials and 133 adding over it $10 \mu \mathrm{L}$ of the standards solution at different concentration levels. Once the 134 equilibrium was reached these vials were analysed by HS-SPME-GC-MS.

\section{Instrumental}

137 GC-TOF-MS electron ionization and chemical ionization modes

138 A GCT Premier from Waters Corporation (Milford, MA, USA) was used in both 139 electron ionization (EI) and positive chemical ionization (PCI) modes, the column used 140 was a Rtx $22530 \mathrm{~m} \times 0.25 \mathrm{~mm} \times 0.25 \mu \mathrm{m}$ and the volume injected was $2 \mu 1$. Other 141 parameters used are shown in table 1. $H S-G C-M S$ and $H S-S P M E-G C-M S$

144 A CTC Analytics CombiPal autosampler from Agilent was used. The autosampler was 145 coupled to a 5975B Agilent gas chromatograph connected to a $6890 \mathrm{~N}$ mass 146 spectrometer, the parameters selected for the HS and the SPME analysis are shown in 147 table 2.

\section{Results and discussion}

\section{GC-TOF-MS electron ionizaton and chemical ionization modes}

151 The first step in the screening was to study the pure adhesive formulations in their liquid 152 state. Liquid extraction with acetonitrile was applied to the adhesive and GC-MS-TOF 153 was used for the analysis after removing the precipitated polymeric phase by filtration.

154 Electron ionization (EI) was used initially and chemical ionization was further applied to confirm the compound assignments and to check the reliability of the system for 156 screening. The same procedure was applied to all the adhesive samples. Figure 1 shows 157 the chromatogram obtained from the pure adhesive 3 extract using GC-TOF-MS in 158 electron ionization mode. Table 3 lists the compounds identified by this method in the 3 159 adhesives. Deconvolution of the peaks and identification of the compounds were done 160 using Chromalynx combined with NIST 08 library. This software establishes a list of 161 the most feasible candidates according to the match factor obtained comparing the mass 162 spectrum of the unknown compound with those contained in the NIST database. The 163 match factor is a measure of the certainty of the library search result and ranges from 0 164 to 1000. Afterwards, for the 5 fragments the most abundant of the spectrum, it calculates the mass difference $(\Delta \mathrm{mDa})$ between the accurate masses of the detected 
166 fragments and the accurate masses of the candidate fragments. With all these data the 167 software assigned or did not assign identification for the compound.

169 EI columns in table 3 show the molecular formula of the main fragment, its accurate 170 mass and the mass difference between the experimentally obtained mass fragment and 171 the theoretical mass value of the proposed compound. Even though table 3 shows the 172 data for the main fragment, mass difference was calculated for five fragments in each 173 compound. This technique enabled a reliable identification even for those compounds 174 with a low match. A total of 42 volatiles were detected by EI in the adhesives studied. 175 Most of the compounds found were esters, probably coming from the polymer involved 176 in the formulation; some alcohols, alkanes and alkoxy groups were also found. Four 177 halogenated compounds were found in adhesives 1 and 3.

179 To confirm the identification and complete as much as possible the screening, chemical 180 ionization (CI) GC-TOF-MS was applied to the acetonitrile extracts. Figure 2 shows the 181 chromatogram obtained from the pure adhesive 3 extract using GC-TOF-MS in CI 182 mode. In the CI mode pseudo molecular ions $[\mathrm{M}+\mathrm{H}]^{+}$are detected, being the molecular 183 mass a good confirmation of the compound. Again the identification was based on the 184 comparison between the theoretical accurate mass of the proposed compound and the 185 experimental accurate mass, and the match factor from EI experiments. This technique 186 allowed us to identify 14 unknown compounds and in addition, it was possible to 187 confirm 17 compounds previously identified. A total of 56 compounds were detected, 188 even though the three adhesives were acrylic based, only 9 of the volatiles were found 189 in more than one sample. These results showed the variability of adhesive formulations 190 even though the three samples were acrylic-base and some similarities could be 191 expected. This gives an idea of the complexity of the adhesives and emphasizes even 192 more the importance of the study.Table 3 shows the compounds identified in the three 193 adhesives using CI mode. For some compounds CI provided a higher sensitivity than 194 EI. Some of these compounds, such as 1-1-hexanol-2-ethyl, n-butyric acid 2-ethylhexyl 195 ester or 3(2H)-isothiazolone-2-methyl were found in adhesives where they had not been 196 detected by EI. New compounds were also found by CI such as 4-heptanone, 3-methyl, 197 2-propanone, 1-bromo, acetic acid,2-ethylhexyl ester, guanidine, 2-propenoic acid,2198 ethylhexyl ester, hexanoic acid, 2-ethyl-,2-methylpropyl ester, 2,5-pyrrolidinedione, 1199 (benzoyloxy)-, ethanol2(2butoxyethoxy), ethanol,2(2-butoxyethoxy) acetate, 1- 
200 dodecanol, 2,4,7,9-tetramethyl-5-decyn-4,7-diol and phenol 2,4-bis(1,1-dimethylethyl).

201 Toxtree v 1.51 (Ideaconsult LTD) was used to estimate the toxicity according to Cramer rules (Cramer 1978). Cramer rules classify the compounds in three levels of toxicity depending on its chemical structure and propose a maximum daily intake for each compound depending on its toxicity. The maximum intake is 3.0, 0.91 and 0.15 $\mathrm{mg} /$ bodyweight $\mathrm{Kg} /$ day for class I, II and III respectively. Some of the compounds found in these adhesives, such as guanidine or 2,4,7,9-tetramethyl-5-decyn-4,7-diol and phenol 2,4-bis(1,1-dimethylethyl) had a high toxicity (Class III, Cramer list). 2,4,7,9Tetramethyl-5-decyn-4,7-diol, nevertheless, was considered as moderate toxic by EPA that means a LOAEL (lowest observed adverse effect level) of 200mg/Kg/day. From this study, it could be confirmed that GC-TOF-MS is a powerful tool for adhesives screening. The use of 2 different ionization modes allowed a more reliable identification of the compounds detected. However, once the adhesive has been applied to the substrates and cured the extraction with acetonitrile will not be so exhaustive and another screening methodology with higher sensitivity, especially for the more volatile compounds, is necessary. For these reason, HS-SPME-GC-MS analysis were carried

The HS-SPME-GC-MS technique is based on the sorption properties of the stationary phase bonded to the microfiber, and therefore the selection of the appropriate microfiber

Headspace GC-MS is the most commonly applied technique for the screening of volatile compounds when concentrations are high, as only a portion of the vapour in equilibrium is analysed, while the technique based on SPME is used at lower concentration levels since it is more sensitive due to the pre-concentration step that takes place before injection into GC-MS. Both techniques were checked in this case for screening purposes and applied under the experimental conditions described above.

$$
\text { is a key point. The first step was the selection of the SPME fibres and the optimization }
$$
of the parameters for the HS-SPME analysis. This optimization was done for one of the 
234 adhesives. As all the samples studied were acrylic adhesives and had similar chemical 235 characteristics, the optimized method was applied to all of them.

236 Three SPME fibers were checked for the optimization, a polyacrylate fiber, a PDMS

237 fiber and a PDMS/DVB fiber. Finally, the polyacrylate fiber was selected for the study

238 since it showed the best sensitivity and the highest number of compounds detected 239 (Figure 3).

240

241 The number of compounds detected with the polyacrylate fiber was higher than the 242 number of compounds detected by HS-GC-MS, and the intensity of the peaks was also 243 higher when using the SPME. This result confirmed that SPME was much more 244 sensitive as even compounds present at very low concentration in the laminate, where 245 the amount of adhesive was about $2 \mathrm{mg}$, were detected. Therefore this technique was 246 selected to study the adhesives composition.

248 The software MODDE 6.0 (Umetrics $\mathrm{AB}$ ) was used for the optimization of the 249 parameters for the HS-SPME and a Plackett Burman model was selected for this 250 purpose. Three variables were optimized: extraction time (5-30 $\mathrm{min})$, extraction 251 temperature $\left(40-80^{\circ} \mathrm{C}\right)$ and desorption time (1-10 min).Finally, the optimum conditions 252 were as follows: extraction temperature $80^{\circ} \mathrm{C}$, extraction time 25 minutes and desorption 253 time 1 minute.

255 The compounds identified using this method are shown in Table 4. Comparing these 256 data with those obtained by GC-TOF-MS, a considerably reduced number of substances were found in SPME. This could be expected, since the samples analysed by SPME were laminates, with a low quantity of adhesive (about $2 \mathrm{mg}$ ), while pure adhesives were analysed by GC-TOF-MS. Some of the compounds found such as 1-hexanol-2ethyl and 2-ethylhexylacetate were probably impurities of the monomers used to form the polymer and 2 propenoic acid, 2-ethylhexyl ester were residual monomers. Other compounds found were common additives used in adhesive formulations, 1-dodecanol is used combined with the monomer to form the polymer, and 2,4,7,9-tetramethyl-5decyne-4,7-diol is a surfactant ..

266 Analytical features obtained for some compounds are shown in table 5. Good detection

267 limits were obtained, all of them below $0.8 \mathrm{ng} / \mathrm{dm}^{2}$ and reproducibility was always 
below $9 \%$ with an average value of around $6 \%$. These results confirm that HS-SPMEGC-MS is a valuable tool for the screening of volatile compounds coming from laminates, since it allows detecting compounds at very low concentration levels.

\section{Migration studies and quantitative values}

273 The presence of many compounds in the packaging material does not necessarily imply

274 that they will migrate. In fact, it is expected that most of them remain in the adhesive or 275 in the material layers at both sides of the adhesive. Therefore a migration test will be necessary. Since some of the laminates were manufactured using paper in one side, liquid simulants could not be used for the tests. For this reason, PE was used as receptor for a quick test of the "migration potential" of the compounds identified in the laminates, as it is well known that in general compounds diffuse very fast through it. The test was carried out at $40^{\circ} \mathrm{C}$ simulating the conditions used in migration tests for food contact materials at room temperature (Council Directive 82/711/EEC). PE was in contact with the laminate for 1 hour since it was observed that this time was enough for the compounds to reach the equilibrium. Nevertheless it should be taken into account that due to the low polarity of $\mathrm{PE}$, the migration of very polar compounds could be underestimated with this test. The results from these migration studies are shown in table 5. None of the detected compounds were found previously in the virgin PE films. As it can be seen, the concentrations ranged from 0.04 to $1.6 \mu \mathrm{g} / \mathrm{dm}^{2}(0.11$ to $4.4 \mu \mathrm{g} / \mathrm{g})$ of PE in the PP side and from 0.27 to $28 \mu \mathrm{g} / \mathrm{dm}^{2}(0.74$ to $75 \mu \mathrm{g} / \mathrm{g})$ in the paper side. The concentration of the compounds was always higher in the paper side, as it was expected due to the porosity of the paper. The most toxic compound detected in the screening, 2,4,7,9-tetramethyl-5-decyne-4, was not found in none of the sides. After applying a 6 $\mathrm{dm} 2$ to $1 \mathrm{~kg}$ food simulant conversion factor (Directive 82/711/EEC) the maximum value found in the PP side, that will be the side in contact with the food, was $9.8 \mu \mathrm{g} / \mathrm{Kg}$ of polyethylene, being $10 \mu \mathrm{g} / \mathrm{Kg}$ the maximum migration value which has been accepted as of no concern (Directive 2007/19/EC) This study proved that the HSSPME-GC-MS technique could be used for screening purposes as well as for quantitative determination in migration studies from solid materials, even to quantify levels of non concern. The determination of diffusion and partition coefficients, which are important data for migration modelling, can be also determined by applying this 


\section{Conclusions}

304 Two analytical techniques, the GC-TOF-MS and HS-SPME-GC-MS were optimized for

305 screening the volatile compounds coming from the adhesives used in real packaging

306 materials such as laminates. A huge variability of compounds was found among the

307 adhesives studied. Both techniques provided useful information, nevertheless, the HS-

308 SPME-GC-MS was selected for the future study of migration processes, as it was a fast,

309 reliable and very sensitive method and it did not require sample handling.

310

311 Acknowledgements

312 This work has been supported by the European Union under the Collective Research 313 Programme Contract No. COLL-CT2006-030309 MIGRESIVES. The findings and 314 conclusions in this paper are the responsibility of the authors alone and should not be 315 taken to represent the opinion of the European Commission. Financial support has been 316 received also from Grupo Consolidado de Investigación T-10 from Gobierno de 317 Aragón, Spain. E. Canellas acknowledges the grant from Gobierno de Aragón. 


\section{References}

320

Ashley RJ, Cochran MA, Allen KW. 1995. Adhesives in packaging. Int. J. Adhesion 322 and Adhesives 15: 101-108.

Batlle R, Sanchez C, Nerin C. 1999. A systematic approach to optimize solid-phase microextraction. Determination of pesticides in ethanol water mixtures used as food simulants. Analytical Chemistry 71: 2417-2422.

Bianchi F, Careri M, Conti C, Musci M, Vreuls R. 2007. Comparison of comprehensive two-dimensional gas chromatography time-of-flight mass spectrometry and gas chromatography-mass spectrometry for the qualitative characterisation of roasted barley by solid-phase microextraction. Journal of Separation Science 30: 527-533

Booth K. 1990. Industrial Packaging Adhesives. Blackie. ISBN 0216927951, 9780216927957

336 Council Directive 82/711/EEC laying down the basic rules necessary for testing

337 migration of the constituents of plastic materials and articles intended to come into 338 contact with foodstuffs.

340 Cramer GM, Ford RA, Hall RL. 1978. Estimation of Toxic Hazard. A Decision Tree 341 Approach. J. Cosmet. Toxicol 16: 255-276

343 da Silva GA, Augusto F, Poppi RJ. 2008 .Exploratory analysis of the volatile profile of 344 beers by HS-SPME-GC. Food Chemistry 111: 057-1063

346 Domeño C, Munizza G, Nerin C. 2005. Development of a solid-phase microextraction

347 method for direct determination of pentachlorophenol in paper and board samples:

348 Comparison with conventional extraction method. Journal of Chromatography A, 1095: 349 $8-15$ 
351 European Commission. Directive 2002/72/EC relating to plastic materials and article 352 intended to come into contact with foodstuffs.

354 European Commission. Directive 2007/19/EC Commission Directive of 2 April 2007 355 amending Directive 2002/72/EC relating to plastic materials and articles intended to 356 come into contact with food and Council Directive 85/572/EEC laying down the list of 357 simulants to be used for testing migration of constituents of plastic materials and articles 358 intended to come into contact with foodstuffs.

359

360 Figge, K. 1996. Plastic Packages for Foodstuffs (Stuttgart:Wissenschaftliche) 361

362 Gruner A, Piringer O. 1999. Component migration from adhesives used in paper and 363 cardboard packaging for foodstuffs. Packag. Tecnol. Sci. 12: 12-28

Hao CY, Headley JV, Peru KA, Frank R, Yang P, Solomon KR. 2005. Characterization and pattern recognition of oil-sand naphthenic acids using comprehensive twodimensional gas chromatography/time-of-flight mass spectrometry. Journal of Chromatography A 1067: 277-284

Jickells, S.M. 1997. Possible control measures for paper and board. Work shop on paper and board in food contact applications, 28-29, European commission Joint Research 372 Centre.

373

374 Lopez P, Huerga MA, Batlle R, Nerin C. 2006. Use of solid phase microextraction in 375 diffusive sampling of the atmosphere generated by different essential oils. Analytica 376 Chimica Acta 559: 97-104

378 Mamyrin B.A. 2000. Time of flight mass spectrometry (concepts, achievements and 379 prospects). International Journal of Mass Spectrometry 206: 251-266.

381 Marsman JH, Wildschut J, Evers P, de Koning S, Heeres HJ. 2008. Identification and 382 classification of components in flash pyrolysis oil and hydrodeoxygenated oils by two383 dimensional gas chromatography and time-of-flight mass spectrometry. Journal of 384 Chromatography A. 1188: 17-25 
385

386 Marsman JH, Wildschut J, Mahfud F, Heeres HJ. 2006. Identification of components in

387 fast pyrolysis oil and upgraded products by comprehensive two-dimensional gas 388 chromatography and flame ionisation detection. Journal of Chromatography A 1150: $389 \quad 21-27$

390

391 Meruva NK, Penn JM, Farthing DE. 2004. Rapid identification of microbial VOCs from 392 tobacco molds using closed-loop stripping and gas chromatography/time-of-flight mass 393 spectrometry. Journal of Industrial Microbiology \& Biotechnolog 31: 482-488 394

395 Nerín C, Salafranca J, Aznar M and Batlle R. 2009. Critical review on recent 396 developments in solventless techniques for extraction of analytes. Analytical and 397 Bioanalytical Chemistry 393:809-833

398 Nerín C, Rubio C, Salafranca J, Batlle R. 2000. The simplest sample treatment 399 techniques to assess the quality and safety of food packaging materials. Reviews in $400 \quad$ Analytical Chemistry 19: 435-465.

401 Nerín C, Philo MR, Salafranca J, Castle L. 2002. Determination of bisphenol-type 402 contaminants from food packaging materials in aqueous foods by solid-phase 403 microextraction-high-performance liquid chromatography. Journal of Chromatography 404 A 963: 375-380.

405

406 Pawliszyn J. 1997. Solid Phase Microextraction: Theory and Practice,Wiley-VCH, New 407 York

408

409 Pawliszyn J. 1999. Application of solid phase Microextraction, Royal Society of 410 Chemistry, Cambridge.

411

412 Pena RM, Barciela J, Herrero C, Garcia-Martin S. 2008. Headspace solid-phase 413 microextraction gas chromatography-mass spectrometry analysis of volatiles in orujo 414 spirits from a defined geographical origin. Journal of agricultural and food chemistry 415 56: $2788-2794$ 
417 Resolution AP (2002) on paper and board materials and articles intended to come in

418 contact with food stuff

419

420 Salafranca J, Batlle R, Nerin C. 1999. Use of solid-phase microextraction for the 421 analysis of bisphenol A and bisphenol A diglycidyl ether in food simulants. Journal of 422 Chromatography A 864: 137-144

423

424 Setkova L, Risticevic S, Pawliszyn J. 2007. Rapid headspace solid-phase 425 microextraction-gas chromatographic-time-of-flight mass spectrometric method for 426 qualitative profiling of ice wine volatile fraction - I. Method development and 427 optimization. Journal of Chromatography A 1147: 213-223.

428

429 Wercinski A.S. 1999. Solid Phase Microextraction: A practical Guide, Marcel Dekker, 430 New York.

431

432 Yang ZY, Maruya KA, Greenstein D, Tsukada D, Zeng EY. 2008. Experimental 433 verification of a model describing solid phase microextraction (SPME) of freely 434 dissolved organic pollutants in sediment porewater. Chemosphere 72: 1435-1440 435 436 437 438 439 440 441 
Table 1: Instrument parameters for the GC-TOF-MS analysis

\begin{tabular}{|c|c|c|c|}
\hline $\begin{array}{l}\text { Instrumentation } \\
\text { Ionization mode }\end{array}$ & & EI & $\mathrm{CI}$ \\
\hline \multirow[t]{3}{*}{ GC conditions } & Gas flow $\left(\mathrm{ml} \mathrm{min}^{-1}\right)$ & 1 & 1 \\
\hline & Injector $\left({ }^{\circ} \mathrm{C}\right)$ & 230,splitless & 230,splitless \\
\hline & Oven & $\begin{array}{l}60^{\circ} \mathrm{C}, 5 \mathrm{~min} ; 5^{\circ} \mathrm{C} \mathrm{min}^{-1} ; \\
220^{\circ} \mathrm{C} 6 \mathrm{~min}\end{array}$ & $\begin{array}{l}60^{\circ} \mathrm{C}, 5 \mathrm{~min} ; 5^{\circ} \mathrm{C} \mathrm{min}^{-1} ; \\
220^{\circ} \mathrm{C} 6 \mathrm{~min}\end{array}$ \\
\hline \multirow[t]{3}{*}{ MS conditions } & Ionization mode & $\mathrm{EI}+$ & $\mathrm{CI}+$ \\
\hline & Mass range & $50-800$ & $50-800$ \\
\hline & Reaction gas & No & Methane \\
\hline
\end{tabular}


Table 2. Instrument parameters for the HS- GC-MS and HS-SPME-GC-MS analysis

\begin{tabular}{|c|c|c|}
\hline Instrumentation & & \\
\hline \multirow[t]{3}{*}{ CombiPal HS } & Preincubation time (s) & 120 \\
\hline & Incubation Temperature $\left({ }^{\circ} \mathrm{C}\right)$ & 80 \\
\hline & Volume extracted (mL) & 1 \\
\hline \multirow[t]{5}{*}{ CombiPal HS-SPME } & Preincubation time (s) & 120 \\
\hline & Incubation Temperature $\left({ }^{\circ} \mathrm{C}\right)$ & 80 \\
\hline & Extraction time (s) & 1500 \\
\hline & Desorption time (s) & 60 \\
\hline & Postfiber condition time (s) & 1200 \\
\hline \multirow[t]{5}{*}{ GC conditions } & Column & $\mathrm{DB}-5(30 \mathrm{mx} 0.25 \mathrm{~mm}, 0.25 \mathrm{um})$ \\
\hline & Gas flow $\left(\mathrm{ml} \mathrm{min} \mathrm{m}^{-1}\right)$ & 1.5 \\
\hline & Injector $\left({ }^{\circ} \mathrm{C}\right)$ & 250,splitless \\
\hline & Oven & $40^{\circ} \mathrm{C}, 5 \mathrm{~min} ; 10^{\circ} \mathrm{C} \min ^{-1} ; 300^{\circ} \mathrm{C}$ \\
\hline & & $1 \mathrm{~min}$ \\
\hline \multirow[t]{4}{*}{ MS conditions } & Mass range & $45-400$ \\
\hline & Source $\left({ }^{\circ} \mathrm{C}\right)$ & 230 \\
\hline & Quadrupole $\left({ }^{\circ} \mathrm{C}\right)$ & 150 \\
\hline & Electron energy $(\mathrm{eV})$ & 70 \\
\hline
\end{tabular}


Table 3: Compounds identified in adhesives 1, 2 and 3 by GC-TOF-MS in EI and CI modes, retention times (RT), identification number of the compounds in figures 1 and 2 (No), molecular formula, match factor; main fragment formula, its accurate measured mass and $\Delta \mathrm{mDa}$ for the EI mode; accurate measured mass of $\mathrm{MH}$ and $\Delta \mathrm{mDa}$ for the $\mathrm{CI}$ mode ( $\triangle \mathrm{mDa}$ was calculated referred to the theoretical mass from NIST database)

\begin{tabular}{|c|c|c|c|c|c|c|c|c|c|c|}
\hline \multirow{2}{*}{$\begin{array}{c}\mathrm{RT} \\
(\mathrm{min})\end{array}$} & \multirow{2}{*}{ Compounds } & \multirow{2}{*}{ Adhesive } & \multirow{2}{*}{ No } & \multirow{2}{*}{$\begin{array}{l}\text { Molecular } \\
\text { formula }\end{array}$} & \multirow{2}{*}{$\begin{array}{l}\text { Match } \\
\text { factor }\end{array}$} & \multicolumn{3}{|c|}{ EI } & \multicolumn{2}{|c|}{ CI } \\
\hline & & & & & & $\begin{array}{l}\text { Main fragment } \\
\text { formula }\end{array}$ & $\begin{array}{c}\text { Accurate } \\
\text { mass }\end{array}$ & $\Delta \mathrm{mDa}$ & $\begin{array}{c}\text { Accurate } \\
\text { mass }(\mathrm{MH})\end{array}$ & $\overline{\Delta \mathrm{mDa}}$ \\
\hline 5.1 & $\begin{array}{l}\text { 2-propenoic acid, 2- } \\
\text { methylpropyl ester }\end{array}$ & 2 & & $\mathrm{C} 7 \mathrm{H} 12 \mathrm{O} 2$ & 817 & $\mathrm{C} 3 \mathrm{H} 3 \mathrm{O}$ & 55.0160 & -2.4 & & \\
\hline 5.13 & 2-propenoic acid,methyl ester & 2 & & $\mathrm{C} 4 \mathrm{H} 6 \mathrm{O} 2$ & 748 & & & & 87.0447 & 0.1 \\
\hline 5.2 & 4-heptanone & 2 & & $\mathrm{C} 7 \mathrm{H} 14 \mathrm{O}$ & 926 & $\mathrm{C} 4 \mathrm{H} 7 \mathrm{O}$ & 71.0480 & -1.7 & 115.1131 & 0.8 \\
\hline 5.4 & $\begin{array}{l}\text { propanoic acid,2-methyl- } \\
\text {,butyl ester }\end{array}$ & 2 & & $\mathrm{C} 8 \mathrm{H} 16 \mathrm{O} 2$ & 786 & $\mathrm{C} 4 \mathrm{H} 9 \mathrm{O} 2$ & 89.0600 & -0.3 & 145.1231 & 0.3 \\
\hline 5.83 & 4-heptanone, 3-methyl & 2 & & $\mathrm{C} 8 \mathrm{H} 16 \mathrm{O}$ & 856 & & & & 129.1280 & 0.1 \\
\hline 5.89 & 2-propanone, 1-bromo & 3 & 1 & $\mathrm{C} 3 \mathrm{H} 5 \mathrm{BrO}$ & 891 & & & & 136.9687 & 8.5 \\
\hline 5.9 & $\begin{array}{l}\text { biclyclo[2.2.1]heptan-2-ol, 2- } \\
\text { (2-cyclopenten-1-yl)- }\end{array}$ & 1 & & $\mathrm{C} 12 \mathrm{H} 18 \mathrm{O}$ & 633 & $\mathrm{C} 4 \mathrm{H} 5 \mathrm{O}$ & 69.0331 & -0.9 & & \\
\hline 6.4 & butanoic acid,butyl ester & 2 & & $\mathrm{C} 8 \mathrm{H} 16 \mathrm{O} 2$ & 932 & $\mathrm{C} 4 \mathrm{H} 7 \mathrm{O}$ & 71.0452 & -4.5 & & \\
\hline 6.46 & butanoic acid,butyl ester & 2 & & $\mathrm{C} 8 \mathrm{H} 16 \mathrm{O} 2$ & 911 & & & & 145.1248 & 2.0 \\
\hline 6.7 & pyrazine,2,6-dimethyl- & 2 & & C6H8N2 & 758 & C6H8N2 & 108.0678 & -0.9 & & \\
\hline 7.2 & 4-methoxy-oxazolidin-2-one & 2 & & $\mathrm{C} 4 \mathrm{H} 7 \mathrm{NO} 3$ & 685 & $\mathrm{C} 4 \mathrm{H} 6 \mathrm{O} 2$ & 86.0359 & -0.9 & & \\
\hline 7.7 & 1-butoxy-2-ethylhexane & 1 & & $\mathrm{C} 12 \mathrm{H} 26 \mathrm{O}$ & 847 & $\mathrm{C} 4 \mathrm{H} 9$ & 57.0700 & -0.4 & 187.2049 & -1.3 \\
\hline 8.4 & 2-butenoic acid, butyl ester & 2 & & $\mathrm{C} 8 \mathrm{H} 14 \mathrm{O} 2$ & 852 & $\mathrm{C} 4 \mathrm{H} 7 \mathrm{O} 2$ & 87.0410 & -3.6 & 143.1106 & 3.4 \\
\hline 9.1 & cyclohexanol, 1-butyl- & 1 & & $\mathrm{C} 10 \mathrm{H} 20 \mathrm{O}$ & 632 & C7H15 & 99.1187 & 1.3 & & \\
\hline 9.1 & 1-hexanol-2-ethyl- & $1 / 3$ & 2 & C8H18O & 795 & C6H11 & 83.0753 & -10.8 & 131.1377 & -5.9 \\
\hline 9.1 & 6-dodecanone & 3 & 3 & $\mathrm{C} 12 \mathrm{H} 24 \mathrm{O}$ & 631 & $\mathrm{C} 4 \mathrm{H} 10$ & 58.0779 & -0.4 & & \\
\hline 9.1 & cycloheptanol & 3 & 4 & C7H14O & 561 & $\mathrm{C} 3 \mathrm{H} 5 \mathrm{O}$ & 57.0375 & 3.5 & & \\
\hline
\end{tabular}




\begin{tabular}{|c|c|c|c|c|c|c|c|c|c|c|}
\hline 9.1 & 1-decanol & 3 & 5 & $\mathrm{C} 10 \mathrm{H} 22 \mathrm{O}$ & 807 & $\mathrm{C} 6 \mathrm{H} 11$ & 83.0757 & -10.4 & & \\
\hline 9.1 & 1-hexene,2,5-dimethyl- & 3 & 6 & C8H16 & 740 & $\mathrm{C} 4 \mathrm{H} 8$ & 56.0598 & -2.8 & & \\
\hline 9.7 & acetic acid,2-ethylhexyl ester & $1 / 3$ & 7 & $\mathrm{C} 10 \mathrm{H} 20 \mathrm{O} 2$ & 864 & & & & 173.1552 & 1.1 \\
\hline 9.7 & $\begin{array}{l}\text { 1-pyrrolidinyloxy,3-amino- } \\
\text { 2,2,5,5-tetramethyl- }\end{array}$ & 3 & 8 & $\mathrm{C} 8 \mathrm{H} 17 \mathrm{~N} 2 \mathrm{O}$ & 644 & $\mathrm{C} 4 \mathrm{H} 8 \mathrm{~N}$ & 70.0659 & 0.2 & & \\
\hline 9.9 & benzaldehyde & $1 / 2$ & & $\mathrm{C} 7 \mathrm{H} 6 \mathrm{O}$ & 844 & C7H5O & 105.0341 & 0.1 & 107.0504 & 0.7 \\
\hline 10.1 & $\begin{array}{l}\text { 2-fluorobenzoic acid, } \\
\text { heptadecyl ester }\end{array}$ & $1 / 3$ & 9 & $\mathrm{C} 24 \mathrm{H} 39 \mathrm{FO} 2$ & 791 & $\mathrm{C} 9 \mathrm{H} 17 \mathrm{O}$ & 141.1276 & -0.3 & & \\
\hline 10.3 & 2-butoxyethyl acetate & 3 & 10 & $\mathrm{C} 8 \mathrm{H} 16 \mathrm{O} 3$ & 901 & $\mathrm{C} 4 \mathrm{H} 7 \mathrm{O} 2$ & 87.0446 & 0.0 & 161.1207 & 3.0 \\
\hline 10.5 & guanidine & $1 / 2$ & & $\mathrm{C} 24 \mathrm{H} 39 \mathrm{FO} 2$ & 949 & & & & 60.0481 & -8.0 \\
\hline 10.8 & $\begin{array}{l}\text { 2-fluorobenzoic acid, undecyl } \\
\text { ester }\end{array}$ & 1 & & $\mathrm{C} 18 \mathrm{H} 27 \mathrm{FO} 2$ & 767 & $\mathrm{C} 9 \mathrm{H} 17 \mathrm{O}$ & 141.1272 & -0.7 & & \\
\hline 10.9 & benzene, 1,3,5-triethyl- & 1 & & $\mathrm{C} 12 \mathrm{H} 18$ & 939 & $\mathrm{C} 10 \mathrm{H} 13$ & 133.1008 & -0.9 & 163.1497 & 1.0 \\
\hline 11.5 & propanoic acid, octyl ester & $1 / 3$ & 11 & $\mathrm{C} 11 \mathrm{H} 22 \mathrm{O} 2$ & 754 & $\mathrm{C} 5 \mathrm{H} 10$ & 70.0689 & -9.4 & 187.1695 & -0.3 \\
\hline 11.8 & $\begin{array}{l}\text { 2-propenoic acid,2-ethylhexyl } \\
\text { ester }\end{array}$ & 3 & 12 & $\mathrm{C} 11 \mathrm{H} 20 \mathrm{O} 2$ & 856 & & & & 185.1541 & 0.0 \\
\hline 12.3 & $\begin{array}{l}\text { hexanoic acid, 2-ethyl-,2- } \\
\text { methylpropyl ester }\end{array}$ & 1 & & $\mathrm{C} 12 \mathrm{H} 24 \mathrm{O} 2$ & 829 & & & & 201.1835 & -1.9 \\
\hline 13.0 & $\begin{array}{l}\text { 2,5-pyrrolidinedione, } 1 \text { - } \\
\text { (benzoyloxy)- }\end{array}$ & 2 & & C11H9NO4 & 964 & & & & 220.0610 & 0.0 \\
\hline 13.4 & $\begin{array}{l}\text { n-butyric acid 2-ethylhexyl } \\
\text { ester }\end{array}$ & $1 / 3$ & 13 & $\mathrm{C} 12 \mathrm{H} 24 \mathrm{O} 2$ & 859 & $\mathrm{C} 4 \mathrm{H} 7 \mathrm{O}$ & 71.0498 & 0.1 & 201.1805 & -4.9 \\
\hline 13.8 & octane, 3-ethyl- & 1 & & $\mathrm{C} 10 \mathrm{H} 22$ & 828 & $\mathrm{C} 8 \mathrm{H} 16$ & 112.1238 & -1.4 & & \\
\hline 14.4 & $\begin{array}{l}\text { cyclopentane,(2- } \\
\text { methylbutylidene)- }\end{array}$ & 1 & & $\mathrm{C} 10 \mathrm{H} 18$ & 691 & $\mathrm{C} 8 \mathrm{H} 13$ & 109.1011 & -0.6 & & \\
\hline 15.2 & ethanol2(2butoxyethoxy) & 3 & 14 & $\mathrm{C} 8 \mathrm{H} 18 \mathrm{O} 3$ & 800 & & & & 163.1243 & -9.1 \\
\hline 15.9 & $\begin{array}{l}\text { 3-hydroxypropanoic acid 1- } \\
\text { butyl ester }\end{array}$ & 2 & & $\mathrm{C} 7 \mathrm{H} 14 \mathrm{O} 3$ & 588 & $\mathrm{C} 3 \mathrm{H} 5 \mathrm{O} 3$ & 89.0229 & -1.0 & & \\
\hline 16.2 & decane,1-bromo- & 3 & 15 & $\mathrm{C} 10 \mathrm{H} 21 \mathrm{Br}$ & 900 & $\mathrm{C} 4 \mathrm{H} 8[81 \mathrm{Br}]$ & 136.9800 & 1.1 & & \\
\hline
\end{tabular}




\begin{tabular}{|c|c|c|c|c|c|c|c|c|c|c|}
\hline 16.2 & undecane,1-bromo & 3 & 16 & $\mathrm{C} 11 \mathrm{H} 23 \mathrm{Br}$ & 813 & & & & 235.1120 & 5.8 \\
\hline 18.5 & $\begin{array}{l}\text { ethanol,2(2-butoxyethoxy) } \\
\text { acetate }\end{array}$ & 3 & 17 & $\mathrm{C} 10 \mathrm{H} 20 \mathrm{O} 4$ & 913 & & & & 205.1325 & -11.5 \\
\hline 19.1 & 2-butanone,4-(acetyloxy)- & 3 & 18 & C6H10O3 & 709 & $\mathrm{C} 4 \mathrm{H} 7 \mathrm{O} 2$ & 87.0447 & 0.1 & & \\
\hline 19.2 & $\begin{array}{l}\text { 5-chloro-2-methyl-3(2H)- } \\
\text { isothiazolone }\end{array}$ & $1 / 3$ & 19 & C4H4CINOS & 835 & $\mathrm{C} 4 \mathrm{H} 4 \mathrm{NOS}[35 \mathrm{Cl}]$ & 148.9703 & 0.1 & 149.9791 & 1.1 \\
\hline 19.3 & 1-dodecanol & 2 & & $\mathrm{C} 12 \mathrm{H} 26 \mathrm{O}$ & 879 & C6H11 & 83.0857 & -0.4 & 187.2096 & 3.4 \\
\hline 20.5 & $\begin{array}{l}\text { 2,4,7,9-tetramethyl-5-decyn- } \\
\text { 4,7-diol }\end{array}$ & 3 & 20 & $\mathrm{C} 14 \mathrm{H} 26 \mathrm{O} 2$ & 792 & & & & 227.2011 & 0.0 \\
\hline 20.9 & $\begin{array}{l}3(2 \mathrm{H}) \text {-isothiazolone, } 2- \\
\text { methyl- }\end{array}$ & $1 / 3$ & 21 & C4H5NOS & 881 & C4H5NOS & 115.0019 & -7.3 & 116.0137 & -3.3 \\
\hline 21.4 & $\begin{array}{l}\text { cyclopentane,1,2,3-trimethyl- } \\
\text {,(1a,2a,3a)- }\end{array}$ & 3 & 22 & C8H16 & 718 & $\mathrm{C} 5 \mathrm{H} 10$ & 70.0753 & -3.0 & & \\
\hline 21.4 & $\begin{array}{l}\text { 3,7-dioxo-4,8-dioxa-10-ethyl- } \\
\text { 1-tetradecanol }\end{array}$ & 3 & 23 & $\mathrm{C} 14 \mathrm{H} 26 \mathrm{O} 5$ & 712 & $\mathrm{C} 3 \mathrm{H} 5 \mathrm{O} 2$ & 73.0237 & -5.3 & & \\
\hline 22.2 & $\begin{array}{l}\text { 2-[2-(2-ethoxyethoxy) } \\
\text { ethoxy]ethyl acetate }\end{array}$ & 3 & 24 & $\mathrm{C} 10 \mathrm{H} 20 \mathrm{O} 5$ & 844 & $\mathrm{C} 4 \mathrm{H} 7 \mathrm{O} 2$ & 87.0441 & -0.5 & 221.1389 & 0.0 \\
\hline 23.1 & $\begin{array}{l}\text { 2-butenedioic acid (z)-, } \\
\text { dibutyl ester }\end{array}$ & 3 & 25 & $\mathrm{C} 12 \mathrm{H} 20 \mathrm{O} 4$ & 886 & $\mathrm{C} 4 \mathrm{H} 3 \mathrm{O} 3$ & 99.0080 & -0.2 & & \\
\hline 23.2 & $\begin{array}{l}\text { phenol 2,4-bis(1,1- } \\
\text { dimethylethyl) }\end{array}$ & 3 & 26 & $\mathrm{C} 14 \mathrm{H} 22 \mathrm{O}$ & 883 & & & & 207.1749 & 0.0 \\
\hline 23.2 & $\begin{array}{l}\text { pentanoic acid, 5-hydroxy- } \\
\text {,2,4-t-butylphenyl esters }\end{array}$ & 3 & 27 & $\mathrm{C} 19 \mathrm{H} 30 \mathrm{O} 3$ & 886 & C13H19O & 191.1444 & 0.8 & & \\
\hline 23.4 & $\begin{array}{l}\text { benzoic acid,4-ethoxy-,ethyl } \\
\text { ester }\end{array}$ & 3 & 28 & $\mathrm{C} 11 \mathrm{H} 14 \mathrm{O} 3$ & 872 & $\mathrm{C} 7 \mathrm{H} 5 \mathrm{O} 2$ & 121.0291 & 0.1 & 195.1021 & 0.0 \\
\hline 25.3 & $\begin{array}{l}\text { 2-[2-(2-butoxyethoxy) } \\
\text { ethoxy]ethyl acetate }\end{array}$ & 3 & 29 & $\mathrm{C} 12 \mathrm{H} 24 \mathrm{O} 5$ & 816 & $\mathrm{C} 4 \mathrm{H} 7 \mathrm{O} 2$ & 87.0444 & -0.2 & & \\
\hline 25.5 & $\begin{array}{l}\text { hexanedioic acid, 3-methyl- } \\
\text {,dibutyl ester }\end{array}$ & 2 & & $\mathrm{C} 15 \mathrm{H} 28 \mathrm{O} 4$ & 670 & C7H11O3 & 143.0709 & 0.1 & & \\
\hline 25.8 & $\begin{array}{l}\text { 4,4'-bi-1,3,2-dioxaborolane, } \\
\text { 2,2'-diethyl-, (R*,S*)- }\end{array}$ & 1 & & C8H16B2O4 & 722 & $\mathrm{C} 5 \mathrm{H} 7 \mathrm{O} 2$ & 99.0439 & -0.7 & & \\
\hline 27.2 & phenol, 4-(1,1,3,3- & 1 & & $\mathrm{C} 14 \mathrm{H} 22 \mathrm{O}$ & 932 & $\mathrm{C} 9 \mathrm{H} 11 \mathrm{O}$ & 135.0804 & -0.6 & & \\
\hline
\end{tabular}




\begin{tabular}{|c|c|c|c|c|c|c|c|c|}
\hline & tetraamethylbutyl)- & & & & & & & \\
\hline 27.6 & benzophenone & 3 & 30 & $\mathrm{C} 13 \mathrm{H} 10 \mathrm{O}$ & 913 & $\mathrm{C} 7 \mathrm{H} 5 \mathrm{O}$ & 105.0337 & -0.3 \\
\hline
\end{tabular}


Table 4 . Compounds identified by HS-SPME-GC-MS in adhesives 1, 2 and 3 , retention times $(\mathrm{RT})$ and identification number of the compounds in figure 3 (No).

\begin{tabular}{clcc}
\hline $\begin{array}{c}\text { RT } \\
(\mathrm{min})\end{array}$ & Compounds & Adhesive & No \\
\hline 9.2 & benzaldehyde & 2 & \\
10.72 & 1-hexanol- 2-ethyl & $1 / 3$ & 1 \\
11.9 & undecane & 2 & \\
12.3 & benzene ,1,3,5-triethyl & 1 & \\
12.8 & acetic acid, 2-ethylhexyl ester & $1 / 3$ & 2 \\
13.4 & 2-ethylhexylacrylate & 3 & 3 \\
13.6 & 1-butoxy-2-ethylhexane & 1 & \\
14.0 & ethanol, 2-2(butoxyethoxy) & 3 & 4 \\
14.1 & dimethyl adipate & 3 & 5 \\
15.3 & n-butyric acid, 2-ethylhexyl ester & 1 & \\
16.0 & ethanol, 2-2(butoxyethoxy) acetate & 3 & 6 \\
16.1 & propanoic acid, 2-methyl-,hexyl ester & 2 & \\
16.1 & 3-hydroxypropanoic acid 1-butyl ester & 2 & \\
16.7 & 2,4,7,9-tetramethyl-5-decyne-4,7-diol & 3 & 7 \\
17.3 & 1-dodecanol & 2 & \\
22.97 & butanoic acid, butyl ester & 2 & \\
23.25 & hexanedioic acid, 3-methyl-,dibutyl ester & 2 & \\
\hline
\end{tabular}


Table 5 Concentration of the compounds found in PE from migration experiments expressed as $\mu \mathrm{g} / \mathrm{dm} 2$ of $\mathrm{PE}$ and as $\mu \mathrm{g} / \mathrm{g}$ of $\mathrm{PE}$, limits of

Deleted: 8 detection (LOD) expressed as ng/dm2 of PE and RSD $(\%)$ of the analytical method.

\begin{tabular}{|c|c|c|c|c|c|c|c|}
\hline & \multirow{2}{*}{$\begin{array}{c}\text { laminate PP side } \\
(\mu \mathrm{g} / \mathrm{dm} 2)\end{array}$} & \multirow{2}{*}{$\begin{array}{c}\text { laminate PP } \\
\text { side }(\mu \mathrm{g} / \mathrm{g})\end{array}$} & \multirow{2}{*}{$\begin{array}{c}\text { laminate paper } \\
\text { side }(\mu \mathrm{g} / \mathrm{dm} 2)\end{array}$} & \multirow{2}{*}{$\begin{array}{l}\text { laminate paper } \\
\text { side }(\mu \mathrm{g} / \mathrm{g})\end{array}$} & \multirow{2}{*}{$\frac{\underline{\mathrm{LOD}}}{(\mathrm{ng} / \mathbf{d} \mathbf{m} 2)}$} & \multirow{2}{*}{$\begin{array}{l}\text { RSD } \\
\underline{(\%)} \\
\end{array}$} & \multirow{2}{*}{$\begin{array}{l}\text { Formatted Table } \\
\text { Formatted: Font: Not Bold }\end{array}$} \\
\hline & & & & & & & \\
\hline 1-hexanol-2-ethyl & 0.04 & 0.11 & 0.34 & 0.93 & $\underline{0.79}$ & $\underline{5.5}$ & \\
\hline 2-ethylhexylacetate & 0.05 & 0.13 & $1.2 \mathrm{z}$ & 3.3 & 0.39 & 6.2 & Deleted: 2 \\
\hline Ethanol-2(2 & 0.17 & 0.46 & 3.2 & 8.7 & $\underline{0.59}$ & 6.7 & Deleted: 0 \\
\hline butoxyethoxy) & & & & & & & Deleted: 3 \\
\hline 2-ethylhexylacrylate & 0.04 & 0.11 & 0.58 & 1.5 & 0.39 & 5.3 & Deleted: 3 \\
\hline Dimethyladipate & 0.07 & 0.18 & 0.27 & 0.74 & $\underline{0.79}$ & $\underline{5.4}$ & Deleted: 5 \\
\hline butoxyethoxyacetate) & & & & & & & Deleted: 1 \\
\hline 2,4,7,9-tetramethyl-5- & $\underline{\text { n.d. }}$ & $\underline{\text { n.d }}$ & $\underline{\text { n.d. }}$ & $\underline{\text { n.d. }}$ & $\underline{0.59}$ & $\underline{6.0}$ & Deleted: 7.90 \\
\hline decyne-4 & & & & & & & Deleted: .41 \\
\hline
\end{tabular}

n.d. non detected in the migration experiment 


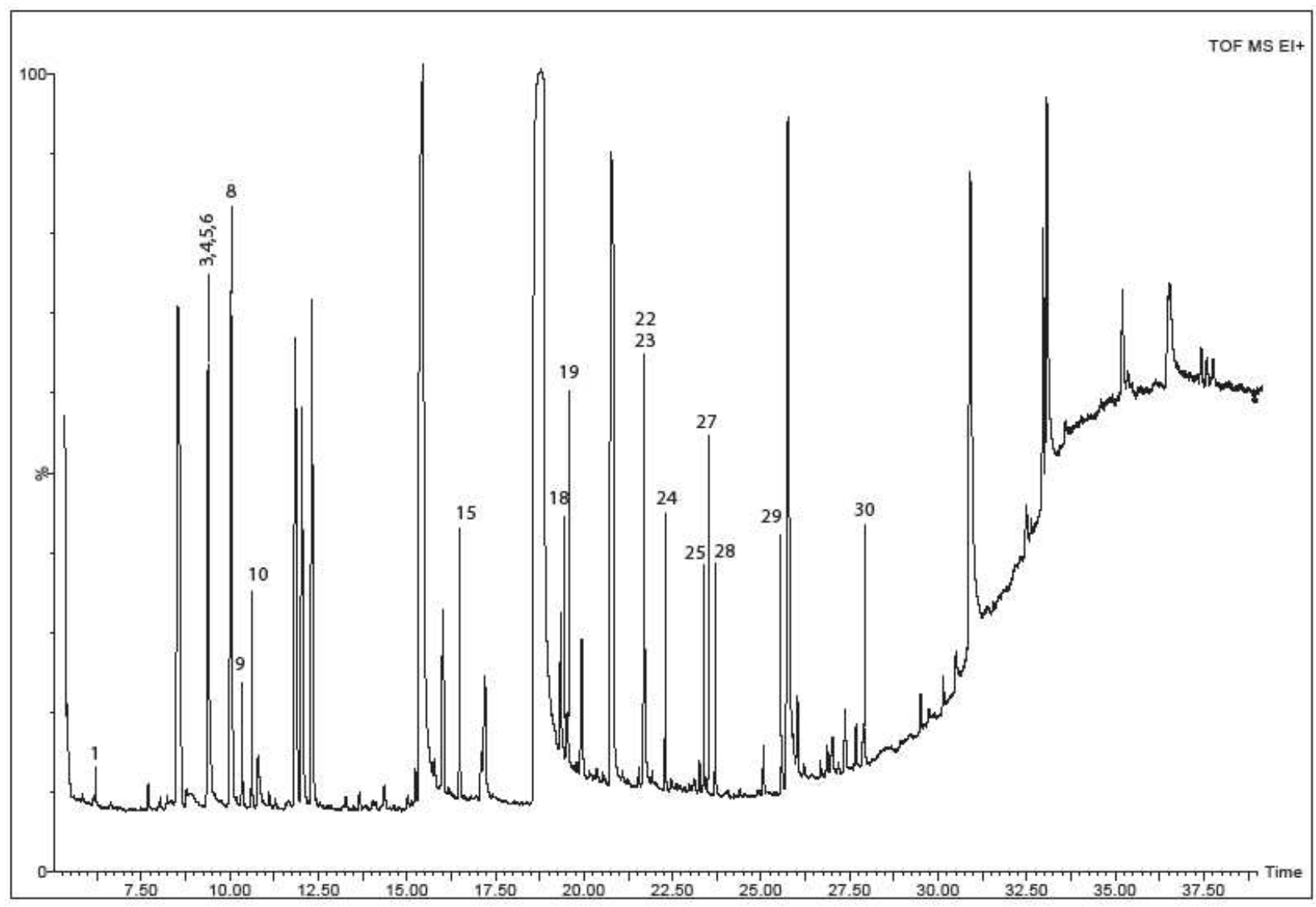

| Figure 1. Chromatogram of adhesive 3 obtained by GC-TOF-MS and EI mode. Identification numbers explained in table 3 


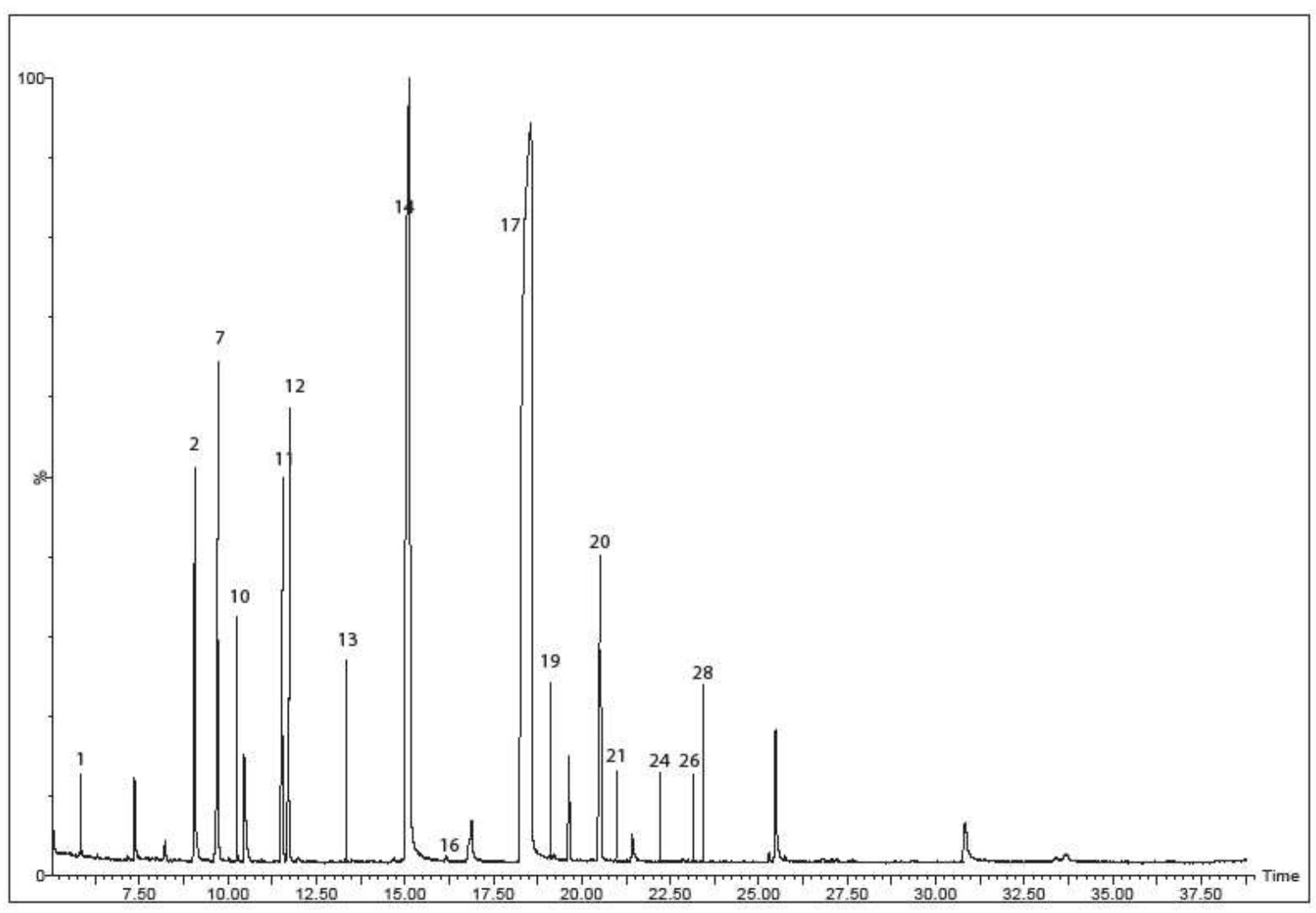

Figure 2, Chromatogram of adhesive 3 obtained by GC-TOF-MS and CI mode. Identification

numbers explained in table 3 . 


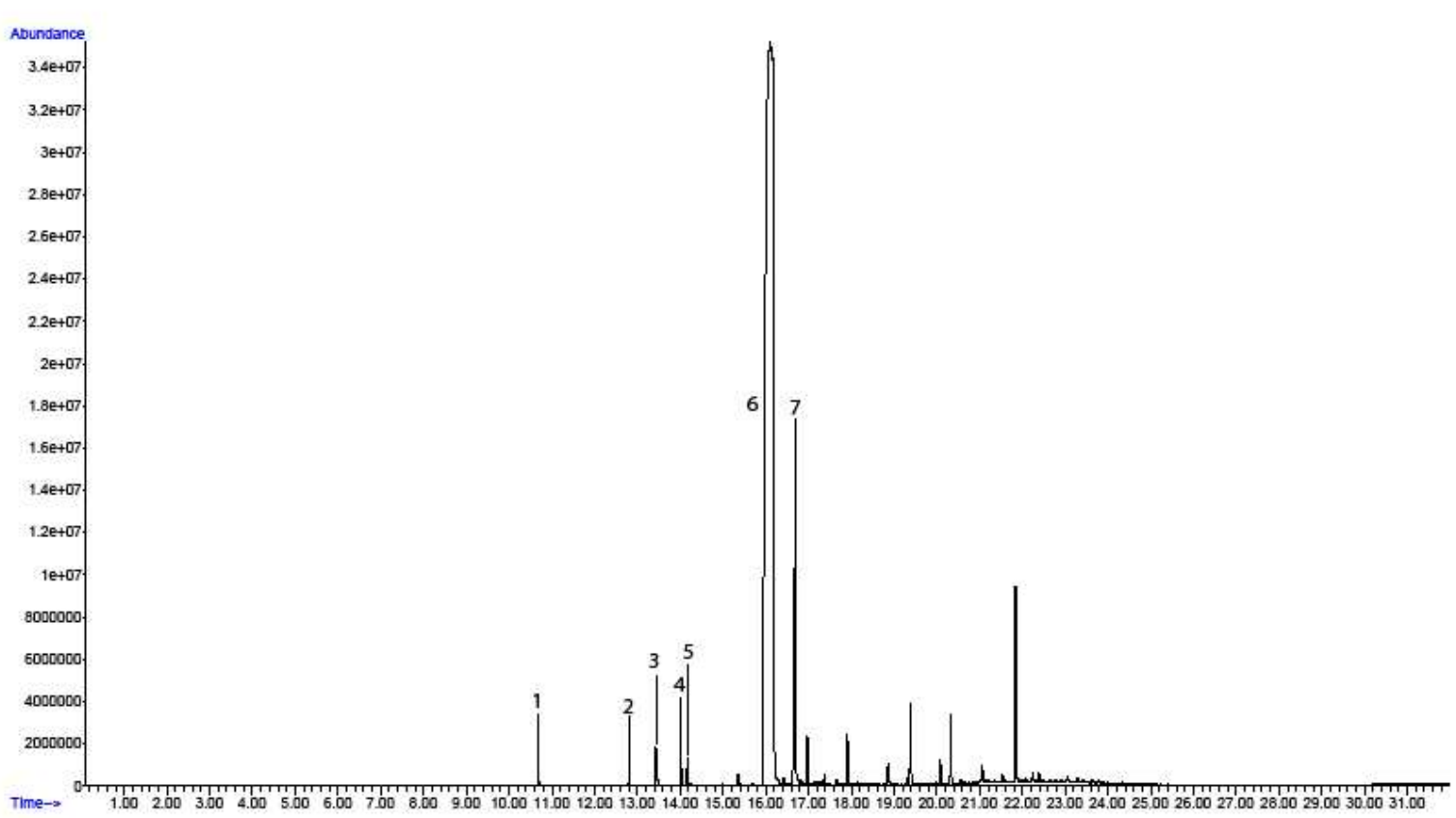

Figure 3 , Chromatogram of laminate 3 obtained by HS-SPME-GC-MS with a polyacrylate fiber Identification numbers explained in table 4. 